\title{
Methodology in Attitudes Assigned to Architecture as Distinctly Regional
}

\author{
Ilze Mikelsone, Riga Technical University
}

\begin{abstract}
Regionalism as a research subject in the built environment indicates notable complexity. This subject is complex by facing multi layered disciplines, it is questioned in time and it has a plural structure, ontological, intellectual and emotional. Presuming that regionalism concepts specifically in architecture are not much more than conjectures and attitudes assigned to $i t$, the purpose of this study is examination of attitudes in order to correlate them with methodological tools.
\end{abstract}

Keywords - Attitudes in architecture, regionalism in architecture, regionalism concepts.

Today's need, if we are ever to understand ourselves and our day, is for the fusion of our knowledge of the structure of nature with the essential reality of everyday human experience, reason and emotion. "This is the 'stuff" of poetry and architecture," write architectural thinkers in seventies [40], [41]. This paper is offered as an introduction to the study of attitudes and representation of architecture as regional and part of a certain region. The regionalism in architecture is seen as "phenomenon", as the product of particular individuals at particular times and places, employing the knowledge and technologies of their day [42]. Like other powerful ideas that make our modern world move, nationalism and regionalism does not stand outside architecture. Instead it is instrumental in shaping of architectural ideologies and practices [27]. But if directly referring the regional identity phenomena to an existing or perspective built-up environment, there is often lack of understanding in regard to how these concepts are constructed, what gives them the meaning and how they are represented in the public domain.

\section{UNBINDING CONJECTURES AND ATTITUDES}

One of the typical terms used in regard to regional architecture is the term "identity". Identity related discourses are generally recognized, popular phenomena of the modern world globally [31], [14], [20] and locally [26], being a concept central to the field of psychology. Establishing a sense of belonging is at the core of identity development for both individuals and groups. Contemporary scholars argue that multiple identities are present, necessary, and even adaptive in today's society [6]. The typical interest in architecture of our time has changed its accents, and we perceive it as a peculiar formation with a plural nature in all its complexity - not only as a concurrently social and technical formation in cultural disposition, but also as liberal, geopolitical and climate-change challenge. Lewicka [30] has identified substantial increase of research on people-place relations during the last three decades, with over 400 articles published in 120 journals across many social science and humanities disciplines, from architecture to human geography [9].

Bauman and Vecchi $[3,20]$ state that the idea of national identity historically arose from the "crisis of belonging", and scholars suggest that nations are invented partly as a response to the need for identity and belonging [1], [12], [17], [18]. National identity is said to provide continuity to the human being, affording a larger human narrative [1]. Specifically, Gellner [13] argues that with the dissolution of status and class, individuals are left to identify with the political [6]. In architecture, "regionalism" is synchronized with many names, such as "local", "national", "typical", and "un-global", "characteristic" or "vernacular", and remains the same concept of belonging and resistance [7] and the same question "what are we like in reference to others" [23] as all the other identity types. Besides the historically recorded claim of a small European nation to have the potential existence of a special, strictly local identity in the spatial domain [28], the image of "regional architecture" has changed and it consists of symbols that are either heritage-focused or contemporarily ambiguous and blurred [35], [5].

According to M.Kūle [27], the research tasks analysing national identity may include clarification of: 1) the main concepts in theoretic research and development of national identities in Latvia; 2) the actual field work, related to the regional identity; 3) the discourse analysis; 4) the identity within the hierarchy of other identities; 5) within interaction of the nationally regional and European identity, 6) its impact on the contemporary processes and more. Transferring this research methodology to architecture and built environment discipline, the research tasks might be classified as follows:

Concepts and definitions of "regional architecture", "architectural identity", "national identity", "pluralism of identities" and "spatial identity" have been constantly raised in timeline [20], [7], [36], [34];

2) Identification of the actual field work, related to regional architecture as part of global building market rules and the result of the opinions of the local civil society. Increasing number of players is competing in the building market, in different typologies and each of them determines the rules and concepts at their own discretion;

3) Discourse analysis as "truth in certain regime of truth" can be an essential approach to the research of regionalism and identity construction in architecture [14], [32]. The depiction of the structure 
Fig. 1. Target fields of attitudes, distinction by identity address field and identity emergence [Picture: I. Miḳelsone].

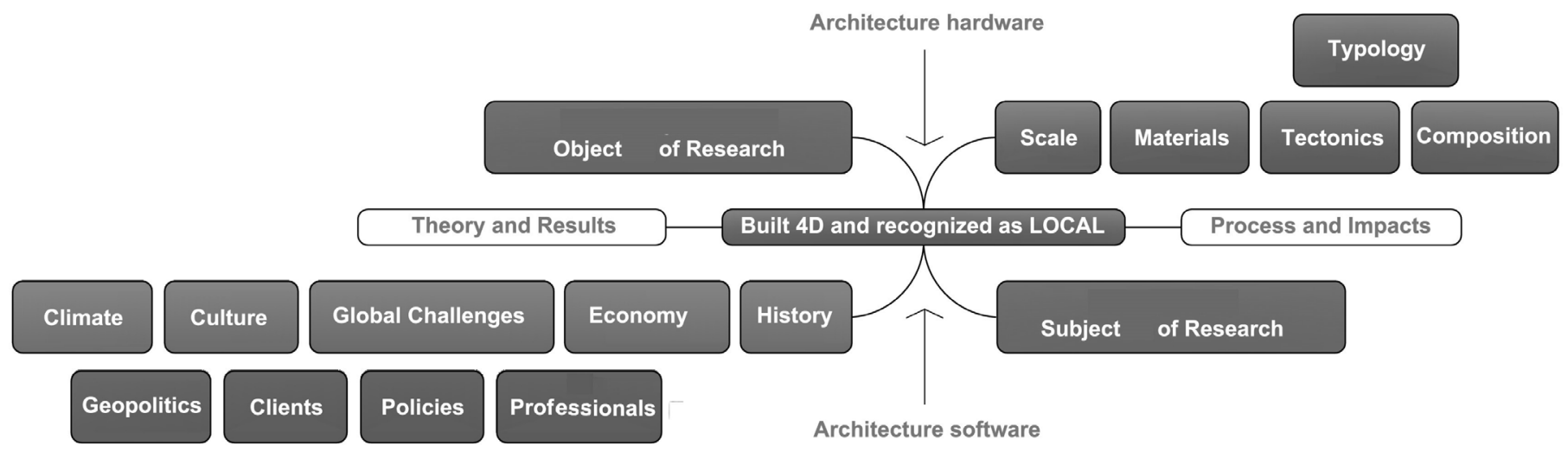

Fig. 2. Sample of synoptic analysis in a graphic form [Picture: I. Miķelsone].

and identity of regional architecture cannot be separated from the context or the specific time period; it includes recursive, self-similar models;

4) Finally, the identity of architecture and the built-up spatial environment within the hierarchy of other identities [20]. Hierarchies might define the criteria in different groups of customers in Latvian society or within interaction of European identity [39] or as its hierarchical impact on the contemporary processes and the sustainable development. The formations might be incomparably different, as theoretical manifestos, philosophical contemplations or sustainable design methods to more or less successful market product for the consumer society. Much architectural research may well focus on the physical outcomes of design from the scale of building components to neighbourhood and urban design-research on the processes of design [16].

Deeper analysis of such complex setting discovers several attitude layers, if they are analysed by focus field (to "whom" they might be targeted) (Fig. 1). It includes attitudes focused on results, which are visible, touchable, and usable, and which might address both individual building and common space. Another group includes attitudes which focus on the phenomenon itself and are a mind construction (invention) of either architect, or historian, or society (client) or mass media. Further, attitudes might be directed into holistic understanding of enormous impact by different processes and extra factors. Finally, besides mind construction attitudes there also exists custom-made emergence, happening as daily routine of multidimensional society (referred to the "background" as K. Fisker named it [21]), which also sets important part of built environment and has to be considered in regional identity phenomena discourse - as certain attitude target.

Assuming that the identity of regional architecture is not an absolute, unexplained truth, but rather the attitudes assigned to it, as "it should be", "it was", and as "it is now", the purpose of this study is examination of attitudes in order to correlate them with methodological tools in the research of regionalism in architecture. Three consecutive approaches to the potential critical appraisal thereof are reviewed in this article. The first approach (A.) stems from the modern formal logic. It is attributed to the identified field of work and problem formulations [19]. The second approach (B.) represents the general historical conjectures and can be attributed to the different systematizations of historical facts, authorities and discourses. The third approach (C.) consists of research methods that are based on the specifics of developments of the contemporary world and the analysis of the ways, in which the issues of identity are updated recently [22], [38]. 

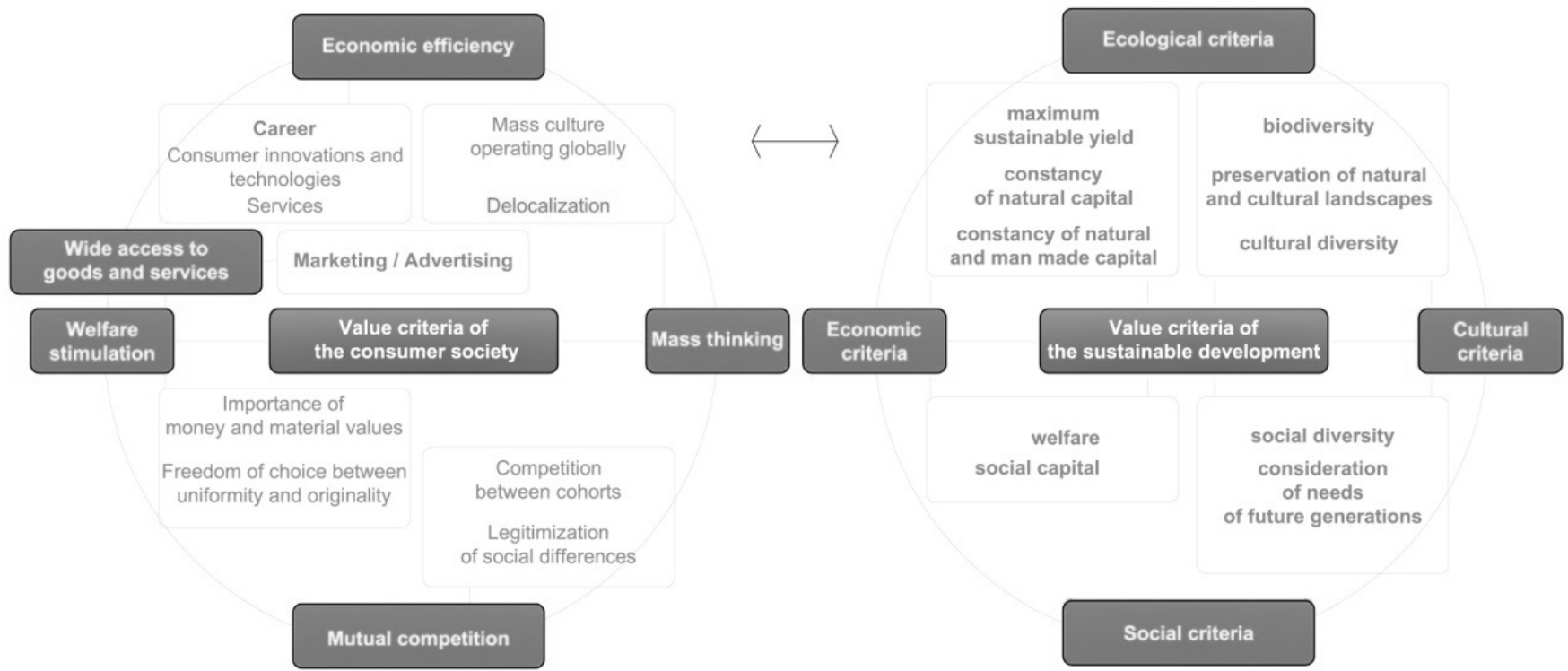

Fig. 3. The problem definition method, as possible mismatch of value criteria. Analysis of value criteria by consumer society by Austruma S. [2, 14] in the context of various dimensions of sustainable development (by A. Bachtold) [22, 9].

A. Formal logic, synoptic overview and problem definition methods

According to G. Hegel, "the richer the object to be defined, i.e., the more different facets has to be viewed, the more varied can be definitions based on it". The huge number of factors to be considered in attempts to understand the basic notions of regional architecture requires looking for methods, which are based primarily in the basic principles of the formal logic, i.e., formulation of definitions, work field and problems.

A.1. Collecting and analysis of theoretical framework allows avoiding misunderstandings and their purpose is to indicate what the concept to be used reflects and to reveal features contained by it [7], [34]. Providing a good definition means not only revealing its content, but also the essence of the definable object, and that requires both separating the definable object from others and determining the structure of the origin of the definable object - whether the definition is based in an emotional, intellectual or ontological ground. Important factor is also dependency on the inquiry level of the definable object [19] in timeline, for example, by the time the concept of regionalism was introduced, it was vis-à-vis modernism, but its resistance focus of today is closer to vis-à-vis globalism.

A.2. Analysis of synopsis and distinctions can be used in order to enable the analysis of the field fragmented in time, space and content. It is an inquiry method, where the "whole research object" (Fig. 2) is divided into components in the sequence from the general towards the individual in a graphic form. The phenomenon under study is perceived as a system, identifying its structure, the top and bottom border of the research scope, but refraining from identifying any processes or changes, or any evaluations.

A.3. Problem definition refers to the hypotheses for defining contradictions, which as being especially important in such research work, might amount to significant part of it, or even be the main objective of the research. A problem situation in general terms is any practical or theoretic situation, which lacks a solution adequate to the circumstances, including difficulties, hesitation or uncertainty [19], in fact, formulating the main research purpose and question [16, 141].

Aptly problem definition example might doubt the significance and structure of the phenomenon. If the substantive application of the identity and its target audience are not clear, the reason for continuous updating of such issues can be identified as a problem framing questionnaires - "why", "who", "for whom" or "by whom". The question "why does architecture have to be regionally identifiable or who needs it" requires clarification whether the cause lies in the requirement of the market, European policies, climate demand, aesthetics, cultural resistance, quality, emotions, self-promotion, exportability or recognition. Uncertainties are also caused by the content application itself - "who is ordering the identity" and "what is the target audience of the identity.

The problem definition could be related to the elusive set of variables and conditions, which "make" the architecture as distinctly regional: the ability to adapt the global trends to the current climate, building as a social turn, building as a cultural heritage, dominating liberation processes or maybe only an individual opinion of a genius.

If the motives created by the modern reality in the spatial domain, which clearly have a strong spatial and visual influence on the regional identity, are not analysed in-depth and critically appraised, the problem might conclude as aporia, - it denotes and substantiates the thesis, which obviously contradicts our experience [19]. For example, such nonconformity could be hidden in different understandings of value systems, where manifests and rather logical statements of professionals clearly 


\section{Past}

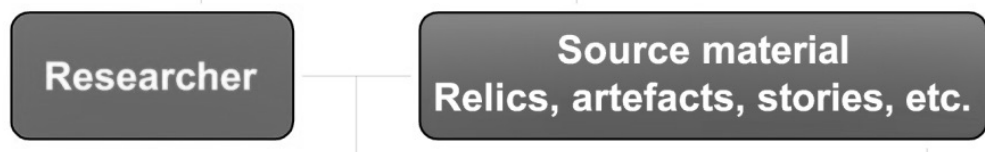

\section{References}

Conclusions from past

\section{Source critic}

Fig. 4. Scheme of historical approach [Picture: I. Miḳelsone].

contradict the value perception model of the consumer society (Fig. 3). The contradiction serves as a proof that the knowledge recorded in the commonly accepted abstracts is too general, one-sided or outdated.

\section{B. Historical approach}

Historical research methods [31], [16] are widely accepted in architectural research (Fig. 4). They are especially suitable and popular in Latvia, because the range of fluctuations of the historical events [25] and the geopolitical dependency of architecture on them has always been important. The popularity of this method is ensured by adherence to the established traditions of treating cultural-historical heritage, as well as representation of several influential personalities of this sector [28], [24].

Generally this approach is divided into the quantitative research methods, which allow gaining quantitative and statistical information on the spread of a certain phenomenon (how often; what part of), for example, evolution of the architectural form of a certain type of building or general trends in style development, and the qualitative research methods, which allow gaining information on the essence and aspect of a certain phenomenon (why; how), for example, expansion of features of the creative work of certain architects [8].

B.1. The monographic (descriptive) method is one of the most traditional methods of creating information summaries. Based on a review of diverse literature, the phenomenon is analysed in detail, describing not only the situation to be researched, but also the changes that have taken place over the time [32].

B.2. Customizable is the comparative (synthesis) method, which explores the correlations for an individual element of the research object in order to make conclusions on structural similarity, parallels, and analogies by form or content. The method allows recording of phenomena, which could be otherwise missed without comparison, for example, "local" or "global" pun [36]. T. Schieder distinguishes two ways of comparison, the paradigmatic comparison - a certain, widespread phenomenon is assumed as common and regional differences are searched for; the analogical comparison - based on the similarity of phenomena, when searching is oriented to the differences, common traits, mutual influences. For example, the communication of national emotions, history of emotion display or terms that dominate in the definitions of nationality oriented emotions in various segments of architecture, as well as time periods of representation history approach differ [32].

B.3. The understanding of regionalism in architecture can be promoted by the critical discourse analysis [32], which focuses on attempts to find answers to questions on social society practice that determined actions - the way we perceive this world. Here discursive information is an important concept the way of sorting and integrating the meanings within the framework of one discourse. The main task of this method is to reveal the perception of a certain time. A certain problem (fact) can be employed to explore how this social world is constructed as truth in certain regimes of truth, and visual narrative of the built-up environment reflects the verdict on the "regionalism" expressed in various forms.

C. Methods of opinion collectivization, qualitative practice and architectural process research

Typical ways of collecting and presenting information are perceived differently in a well verified and stable scientific theory with time distance than in a theory that is still in development and lacks solid foundations [19, 81]. For instance, N. Leach in his book Rethinking architecture (2002) points out the tension in the attitudes that belongs specifically to the world of architects and the ones that are generated "outside" that world [29]. Several trends can be observed of how scientific, practical and theoretical statements of attitudes are made recently (Fig.5). Three of them are mentioned on exploration of architectural identity in this regard.

C.1. The first one is the opinion collectivization method, created to support one or several nominated thesis within the framework of a common event or movement (book, symposium, biennale, triennale). The way thesis is cemented in ideological position often is based on brief summarization of interpretations by reliable and prominent human sources (opinion builders). An example to this is the attempt of the St. Petersburg's curator 


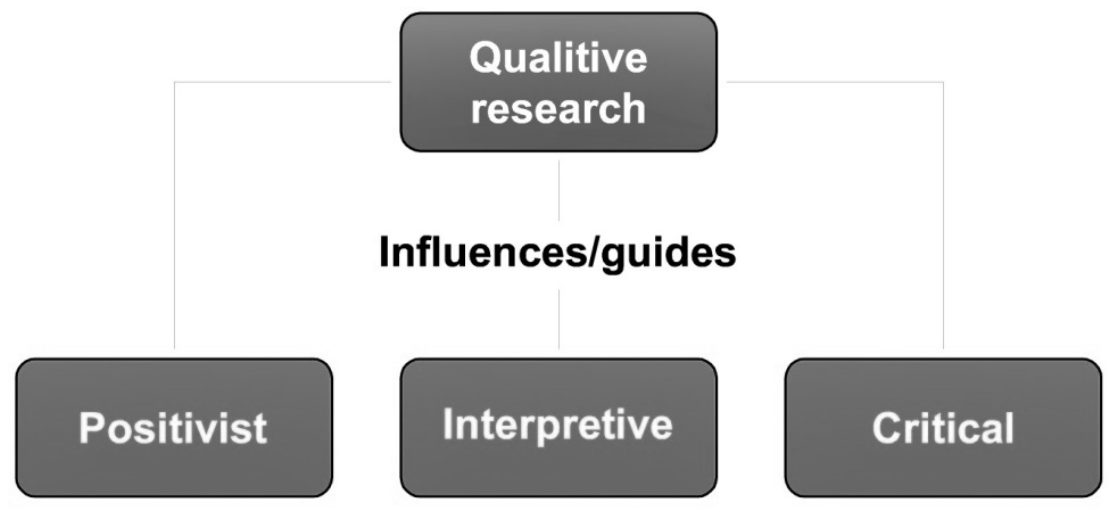

Fig. 5. Qualitative approach scheme [Picture: I.Miķelsone].

V. Frolov [11] to define the identity of the contemporary Nordic architecture. The editors, architects and critics (citizens of Denmark, Norway, Sweden, Finland and Estonia within the project (Moscow, 2012) selected five completed objects from the architectural range of their own country that in their opinion were representing "the Nordic identity". These selections and arguments of the participants allowed the curator to synthesize thematic conclusions and express them in public domain. Similar typical example is the book "V*X Latvian architecture since 1991", the summary of Latvian architecture of the last 20 years, made by the curator K. Budže [37]. Through the perspective of five architectural critics about best samples of Latvian architecture, vision of national architecture in general is discussed. Thus, the press and exhibitions have "become media, through which the majority of the art (architecture) becomes known" [15] and play a crucial role in the articulation and positioning of the art (architecture)". The annual professional award nominations are based on the same principle, - by the summary of expert individual evaluations, either highlighting the "best of the year", or attributing concepts according to the market demands.

C.2. The second method has been used in architectural practice long before and is primarily based on the deep interpretation of "context and content synthesis". The popularity of qualitative practice method lies in the circumstance that in most cases the professionals have to substantiate their actions for themselves and others. Various locally and internationally recognized architects clearly position the design methods employed in their team work as equipped with a critical and sustainable approach to the identity of objects in particular. For example, the Finnish-Austrian bureau "B+P" [4] define their design method as "putting together hard facts like the program, functionality and economy with soft facts like the urban, social and natural landscape, the cultural settings, the climate (...)". This design method enables the office "to create unique projects with a strong and distinctive identity, on a visual, atmospheric and contextual level" [4]. Such attitudes might differ, but all of them can be considered as both difficult to rebut, and still very flexible in argument based attitude.

C.3. The third methodology is based on the assumption that the process of the whole cycle of architecture development within the regional identity formation is not only equal to the process of development of architecture as artifact, but it rapidly becomes dominating. The method of mapping controversies is the thesis stated by A. Yaneva in regard to the existence of an increased potential of the contemporary architecture in the field of various controversies. When analysing the relations of the architectural artifact and process, it has to be concluded that any unit of regional architecture has been developed according to a certain hierarchic in timeline. Although all levels in this scheme are closely interconnected, their representatives do not always have consensus on the expected result; plus power of influence of each "participant" has significantly changed over the time as the process increasingly results in the general term of architecture as "compromise art". As such, according to Yaneva [38], [72] "mapping controversies means 'analysing controversies' and covers the research that enables us to describe the successive stages in the production of architectural knowledge and artifacts, buildings and urban plans. It also refers to a variety of new representational techniques and tools, which describe the stages of controversies." To add German sociologist's H. Rosa's claim, it could be said that "many modern conflicts stem from the fact that some people are simply no longer able to understand the world in all its complexity. The result is a flight into conservatism, which manifests itself in different ways around the world" [33] and this is again - an attitude.

\section{CONCLUSION}

Main conclusion in rebinding attitudes towards regionalism in architecture includes a view that contemporary understanding of regional as "local" architecture is not monolithic and clear. It 

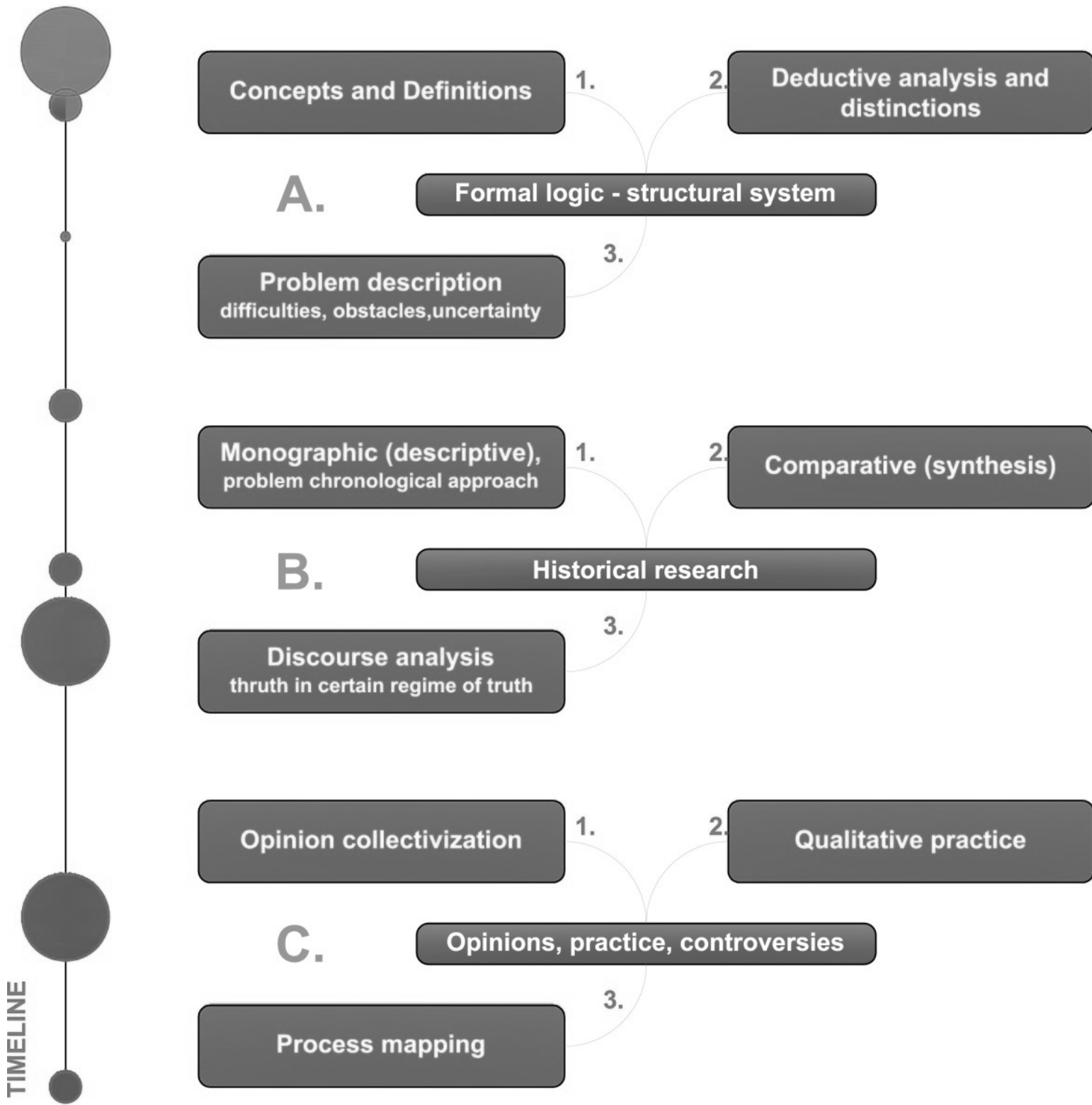

\section{Historical research}

Discourse analysis thruth in certain regime of truth

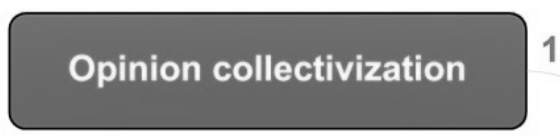

\section{Opinions, practice, controversies}

3.

Fig. 6. Conclusionary abstraction on methodology hidden in conjectures and attitudes assigned to regionalism in architecture [Picture: I. Miķelsone]

is more of a fragment assembly, where exists close engagement and overlapping between methods (Fig. 6).

Formal logic and structural system method allows clarifying basic definitions through attitudes. It is a logical operation that reveals the content of the concept, and exact formulations of the study object are crucial in any complex discourse.

Deductive analysis and distinctions method is especially suitable at the beginning stage of the research when a substantiated selection has to be made for inductive studies. Based on this display of work field, the most suitable distinctions can be methodically selected according to the following criteria: 1) by study objective (analysis); 2) by study results (qualitative, quantitative); 3 ) by options of application.
Problem definition as method includes analysis of particular local difficulties, obstacles or uncertainties. Due to the fact that the causalities of the contemporary regional architecture identity represent problem situations, where the problem still has to be revealed, there are neither methods, nor clear perceptions of what should be considered as a solution to the problem; in order to grasp its real essence, the already known things should be approached from a totally new perspective.

Historical approach in general terms is a systematic set of methods and principles for theoretic analysis of historical materials and sources - artefacts, gaining as impartial and valid information as possible. The monographic (descriptive) method and the problematic chronological approach method allows viewing one or another component of the historical concept 
in its development through problems, which it simultaneously embodies and reflects, whereas if referred not to the architecture in general, but specifically to regional architecture, the comparative or synthesis method and the historical discourse analysis have to be added to it. The critical discourse analysis is appropriate because it works with deeper concepts - knowledge which determines the way we perceive this world, and here discursive information is an important concept - the way of sorting and integrating the meanings within the framework of one discourse.

Methods of opinion collectivization can be considered as a derivation developed from the "expert interview", where it is possible to agree on the definition of a certain phenomenon as the process concludes. Qualitative practice methodology, on the contrary, rarely focuses on the approach devoted to a specific nation or group of nation's - Nordic, Southern, Germanic, etc. It is often emphasized that the method is based on a unique idea, which has developed in close relation to the context and content. The method of architectural process research stems from the position that there is no border between architecture as artefact and architecture as a part of a process.

\section{REFERENCES}

1. Anderson, B. Imagined communities : Reflections on the origin and spread of nationalism. New York: Verso, 2006. 240 p.

2. Austruma, S. Jauniešu vērtības pātērētājsabiedrībā Latvijā, Promocijas darbs, Rēzeknes augstskola, 2012; ISBN 978-9984-44-101-6

3. Bauman, Z., \& Vecchi, B. Identity : Conversations with Bennedetto Vecchi. Cambridge: Polity Press, 2004. 140 p.

4. Berger Parkkinen architekten [cited 19.09.2014]. http://www.bergerparkkinen.com/

5. Britton, K. A Regionalist Panorama for Architecture and Beyond [online]. Metropolitics [cited 30.01.2013]. http://www.metropolitiques.eu/ARegionalist-Panorama-for.html.

6. Buckner, B. The comparative identity of nations : image of nation as an assessment tool of national identity [online]. ProQuest 2011 [cited 19.09.2014]. http://www.proquest.com/products-services/dissertations/

7. Canizaro, V. Architectural Regionalism : Collected Writings on Place Identity Modernity and Tradition. New York: Princeton Architectural Press, 2007. 14 p. ISBN-10:1568986165

8. Chau, H. Xianfeng? Houfeng? Youfeng? : An analysis of selected contemporary Chinese architects, Yung Ho Chang, Liu Jiakun, and Wang Shu (1990s-2000s). Frontiers of Architectural Research, Vol. 4, Issue 2, 2015, p. 146-158. http://dx.doi.org/10.1016/j.foar.2015.03.005

9. Devine-Wright, P. Think global, act local? The relevance of place attachments and place identities in a climate changed world. Global Environmental Change, Vol. 23, Issue 1, 2013, p. 61-69. http://dx.doi. org/10.1016/j.gloenvcha.2012.08.003

10. Drexler, H., EI Khouli, S. Holistic Housing : concepts, design strategies and processes. Bobingen: Kessler, 2012. 288 p. ISBN : 987-3-920034$78-2$

11. Frolovs, A. Mūsdienu ziemeḷnieciskās arhitektūras identitāte, izstāde Nordic ID Maskavas 3. Arhitektūras biennālē 2012 [19.09.2014.]

12. Gellner, E. Nations and nationalism. Ithaca: Cornell University Press, 1983. $208 \mathrm{p}$

13. Gellner, E. Nationalism. New York: New York University Press, 1997. 272 p.

14. Goldstein, E. B. Bayesian approach : Perception as Informational Extraction. Encyclopedia of Perception. Thousand Oaks, California: Sage, 2010, p. 201-206. ISBN:978-1-4129-4081-8

15. Greenberg, R., Ferguson, B. W., Sandy Nairne S. Introduction in Thinking About Exhibitions. London: Routledge, 1996. 512 p.
16. Groat, L. N., Wang, D. Architectural Research Methods, $2^{\text {nd }}$ ed. New York: Wiley, 2013. 480 p.

17. Hall, S. The question of cultural identity. Modernity : An introduction to modern societies [S. Hall, D. Held, D. Hubert, \& K. Thompson, ed.]. Malden: Blackwell, 1996, p. 595-624.

18. Hobsbawm, E. J. Introduction : Inventing traditions. The invention of tradition [E. Hobsbawn, \& T. Ranger, ed.]. London: Routledge, 2008, p. $1-14$.

19. Ivins, A. Pareizas domāšanas māksla. Rīga: Zinātne, 1990. 239 lpp., il ISBN 5 7966 0363-9

20. Jacson, R. L., Hogg M. A. Encyclopedia of Identity : Identity Change. New York: Sage, 2010, p. 359-363.

21. Keidings, M. Ziemeḷu identitāte : seši ievadi [tiešsaiste]. $A 4 D$ [skatīts 19.09.2014]. http://www.a4d.lv/lv/raksti/ziemelu-identitate-sesi-ievadi/

22. Konig, H., Kohler, N., Kreisig, J., Lutzkendorf, Th. A life cycle approach to buildings. Regensburg: Aumuller, 2010. 144 p. ISBN : 978 3-920034-45-4

23. Krastiņš, J. Latvijas arhitektūras nacionālā identitāte. Latvijas Arhitektūra. Rīga, 1989, 5.-20. lpp.

24. Krastin̦š, J. Latvijas Republikas būvmāksla. Rīga: Zinātne, 1992. 236 lpp. ISBN 5 7966-0849-5

25. Krastin̦š, J., Spārītis O. Architecture of Riga : Eight Hundred Years Mirroring European Culture. Riga: Nacionālais apgāds, 2005. 179 p.

26. Kūle, M. Nacionālā identitāte Latvijā un eiropeiskā identitāte [tiešsasite]. Latvijas Nacionālā bibliotēka [skatīts 10.10.2012]. http://identitate.lnb. lv/2010/12/nacionala-un-eiropeiska-identitate/

27. Kusno, A. The Sage Handbook of Architectural Theory [C.G. Crysler, S. Cairns \& H. Heynen, ed.]. London: Sage, 2012. 776 p. http://dx.doi. org/10.4135/9781446201756

28. Latviešu arhitektu teorētiskie raksti un manifesti 20 . gadsimtā $=$ Latvian Architects: Theoretical Writings and Manifestos in the Twentieth Century [Sast. J. Lejnieks un Z. Redberga]. Rīga: Mantojums, 2007. 175 lpp.

29. Leach, N. Rethinking architecture : A Reader in Cultural Theory. London: Routledge, 2002. 413 p. ISBN 0415128269

30. Lewicka, M. What makes neighborhood different from home and city? Effects of place scale on place attachment. Journal of Environmental Psychology, Vol. 30, Issue 1, 2010, p. 35-51. http://dx.doi.org/10.1016/j. jenvp.2009.05.004

31. Mathison, S. Representation, Reporting, Communicating. Encyclopedia of Evaluation. Vancouver: Sage, 2005. 520 p. ISBN: 9780761926092

32. Kategorija: metodes [tiešsaiste]. Vēstures skaidrojošā vārdnīca [skatīts 01.09.2014]. http://www.vesture.eu

33. Rosa, H. Beschleunigung und Entfremdung. Berlin: Suhrkamp, 2015. $154 \mathrm{~S}$.

34. Strautmanis, I. Latviskā telpa. Rīga: RTU Izdevniecība, 2011. 157 lpp. ISBN 978-9934-10-141-0.

35. Tzonis, A., Lefaivre, L. Critical Regionalism : Architecture and Identity in a Globalized World. London: Prestel, 2003. 160 p.

36. Tzonis, A., Lefaivre, L. Architecture of Regionalism in the Age of Globalization : Peaks and Valleys in the Flat World. London, New York: Routledge, 2012. $232 \mathrm{p}$.

37. $\quad V^{*} X$ : Latvijas arhitektūra kopš 1991. gada. Rīga: Nucleus, 2011.

38. Yaneva, A. Mapping controversies in Architecture. London: Routledge, 2012. 144 p. ISBN 9781409426684

39. Zeltiṇa, L. Latviskā identitāte Eiropas identitātes kontekstā = Latvian Identity within European Context. RTU Humanitārās un sociālās zinātnes, 8. krājums, 2006, p. 94-99.

40. Prak, N. L. The Language of Architecture. The Hague, Paris: Mouton \& Co, 1968. 213 p.

41. Langer, S. Philosophy in a New Key [Mentor Books, ed.]. New York: The New American Library, 1951. 255 p.

42. Oakley, D. The Phenomenon of Architecture in Cultures in Change. New York: Pergamon, 1970. 390 p. ISBN 9780080160757 


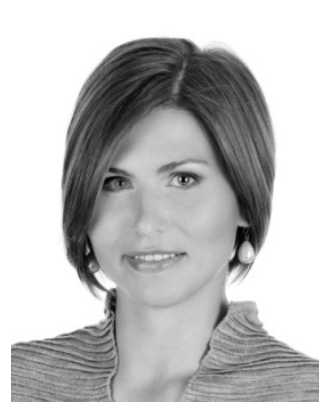

Ilze Mikelsone is graduated as architect (2000) and received the Professional Master Degree in Architecture in the Faculty of Architecture and Urban Planning, Riga Technical University (2012). Since 2012 she proceeds as doctoral student within the same institution. Her main research interest affects challenges and controversies in Architecture of XXI, in aspects of fragmentation, valuation, relationship between theories of regionalism and actions of globalism. Ilze has worked as an architect in architectural offices "SZK Arhitekti" (Latvia) and "Van den Oever, Zaaijer \& Partners", John Bosch (Nederland). Since 2008 runs private architectural practice.

Ilze is the author of the following publications:

- Custom-Made Patchwork Landscape: Entrepreneurial and Private Regionalism; Mokslas - Lietuvos ateitis, Volume 2014, 6(3), pp. 290-302; ISSN: 2029-2341, http://dx.doi.org/10.3846/mla.2014.041

- Quantitative and qualitative parameters of awards in architecture and construction industries of Latvia, Mokslas - Lietuvos ateitis, Volume 2015, 7(1), pp. 89-100. http://dx.doi.org/10.3846/mla.2015.724

\section{CONTACT DATA}

\section{Ilze Mikselsone}

Faculty of Architecture and Urban Planning,

Riga Technical University

Address: 6 Ķīpsalas St., Riga, LV-1048, Latvia

Phone: +371 29469655

E-mail: ilze@taktila.lv 